Gut, 1989, 30, 86-89

Liver, biliary and pancreas

\title{
Effect of peritoneo-venous shunt on portal pressure
}

\author{
A K SAMANTA AND C M LEEVY
}

From the Division of Digestive Diseases, VA Medical Center, East Orange, New Jersey and Sammy Davis, Jr National Liver Institute, New Jersey, Medical School, Newark, New Jersey, USA

Summary The cause of variceal bleed after a peritoneo-venous shunt is not known. Portal haemodynamic consequences of a peritoneo-venous shunt are poorly understood. The most critical period after a peritoneo-venous shunt is the early postoperative period when rapid mobilisation of peritoneal fluid occurs. Serial changes in the portal pressure during the early postoperative period have not been recorded. In the present study preoperative wedged hepatic vein (WHV), right atrial (RA) and pulmonary capillary wedged (PCW) pressures, cardiac index (CI), and plasma volume (PV) were measured in five alcoholic cirrhotic patients with tense ascites for up to 20 hours postoperatively. The longterm effect was assessed by repeating the intrahepatic and/or wedged hepatic vein pressures in three of the surviving patients after 10 to 20 months. A significant increase in the circulatory dynamics and portal pressure was seen within two hours after shunt placement. Wedged hepatic vein pressure increased from $27.6(8 \cdot 2) \mathrm{mmHg}$ to $37 \cdot 2(9 \cdot 2) \mathrm{mmHg}(\mathrm{p}<0 \cdot 01), \mathbf{R A}$ pressure increased from $6 \cdot 8(1 \cdot 5) \mathrm{mmHg}$ to $14 \cdot 0(4 \cdot 3) \mathrm{mmHg}(\mathrm{p}<0 \cdot 05)$, PCW increased from $7 \cdot 2(3.5) \mathrm{mmHg}$ to $19.3(5.7) \mathrm{mmHg}(\mathrm{p}<0.01)$, CI increased from $3.4(0.27) \mathrm{lit} / \mathrm{m}^{2} / \mathrm{min}$ to $4.3(0.85) \mathrm{lit} / \mathrm{m}^{2} / \mathrm{min}^{2}$ $(p<0 \cdot 05)$. This was accompanied by a $34 \%$ increase in the plasma volume from $1838 \cdot 5(142 \cdot 1)$ to $2471 \cdot 4(210) \mathrm{ml} / \mathrm{m}^{2}$. These derangements were maintained up to 20 hours postoperatively. After 10 to 20 months, repeat measurements revealed a return to preoperative measurements. It is concluded that there is an acute increase in portal pressure after a peritoneo-venous shunt attributed to increased circulating plasma volume, resulting from rapid mobilisation of ascitic fluid after the shunt. A sudden increase in portal pressure might be an important provoking factor for variceal bleeding after peritoneo-venous shunt.

Rupture of oesophageal varices has been reported in 9 to $26 \%$ of patients receiving a peritoneo-venous shunt for refractory ascites. ${ }^{1-6}$ Investigations were undertaken to determine the effects of this shunt on hepatic haemodynamics, because an increase ${ }^{7}$ and decrease $^{89}$ in portal pressure has been reported. Measurements of wedged hepatic vein pressure were obtained preoperatively and serially during the first 20 hours to evaluate the acute influence of this procedure; repeat studies were obtained after 10 to 20 months to evaluate the longterm effects.

Address for correspondence: Dr Arun K Samanta, Chief, Digestive Diseases, VA Medical Center (111), East Orange, New Jersey 07019, USA.

Accepted for publication 30 June 1988.
Methods

PATIENTS

Five patients with alcoholic cirrhosis and ascites received a peritoneovenous shunt after they had been treated with and were unresponsive to a $500 \mathrm{mg}$ sodium diet, $250 \mathrm{mg}$ spironolactone and $80-100 \mathrm{mg}$ furosemide daily for four weeks. The preoperative plasma volume, measured by $\mathbf{I}^{131}$ labelled human serum albumin, was increased from a control mean value of $1500(163.3)$ to $1838.5(142.1) \mathrm{ml} / \mathrm{m}^{2}$. Hepatic and cardiac haemodynamics were monitored pre- and postoperatively. Cournand and Swan-Ganz thermodilution catheters were introduced preoperatively in the hepatic vein ${ }^{10}$ and pulmonary 
Table Haemodynamic changes after peritoneo-venous shunt

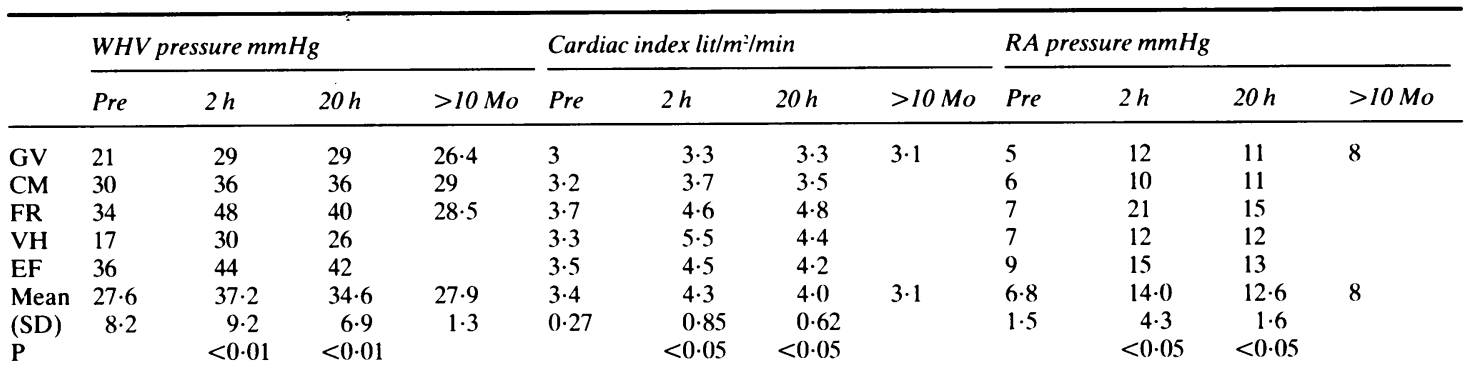

\begin{tabular}{|c|c|c|c|c|c|c|c|c|c|c|c|c|}
\hline & \multicolumn{4}{|c|}{$P A$ mean pressure $\mathrm{mmHg}$} & \multicolumn{4}{|c|}{$P C W$ pressure $\mathrm{mmHg}$} & \multicolumn{4}{|c|}{ SVR dynes/sec/cm } \\
\hline & Pre & $2 h$ & $20 h$ & $>10 \mathrm{Mo}$ & Pre & $2 h$ & $20 h$ & $>10 \mathrm{Mo}$ & Pre & $2 h$ & $20 h$ & $>10 \mathrm{Mo}$ \\
\hline GV & $14 \cdot 8$ & 32 & 30 & \multirow[t]{5}{*}{18} & $7 \cdot 4$ & 17 & 13 & \multirow[t]{5}{*}{6} & 1485 & 1351 & 1157 & \multirow[t]{5}{*}{1434} \\
\hline $\mathrm{CM}$ & 11 & 18 & 15 & & 2 & $10 \cdot 5$ & 10 & & 1170 & 1016 & 978 & \\
\hline FR & $16 \cdot 5$ & 32 & 26 & & $9 \cdot 7$ & 23 & 18 & & 797 & 676 & 560 & \\
\hline $\mathrm{VH}$ & 10 & 31 & 23 & & 6 & 25 & 16 & & 964 & 627 & 746 & \\
\hline $\mathrm{EF}$ & 14 & 23 & 22 & & 11 & 21 & 14 & & 1222 & 1080 & 1135 & \\
\hline Mean & $13 \cdot 0$ & $27 \cdot 2$ & $23 \cdot 2$ & \multirow[t]{3}{*}{18} & $7 \cdot 2$ & $19 \cdot 3$ & $14 \cdot 2$ & \multirow[t]{3}{*}{6} & $1127 \cdot 7$ & $949 \cdot 9$ & $915 \cdot 2$ & \multirow[t]{3}{*}{1434} \\
\hline (SD) & $3 \cdot 3$ & $6 \cdot 4$ & $5 \cdot 5$ & & $3 \cdot 5$ & $5 \cdot 7$ & $3 \cdot 0$ & & $262 \cdot 0$ & $300 \cdot 7$ & $257 \cdot 6$ & \\
\hline $\mathbf{P}$ & & $<0.01$ & $<0.01$ & & & $<0.01$ & $<0.01$ & & & $<0.05$ & $<0.01$ & \\
\hline
\end{tabular}

WHV - Wedged hepatic vein; RA - right atrial; PA - pulmonary artery; PCW - pulmonary capillary wedge; SVR - systemic vascular resistance.

artery ${ }^{11}$ respectively and left in place for 20 hours postoperatively. The wedged hepatic vein (WHV), right atrial (RA), pulmonary artery (PA) and pulmonary capillary wedge ( $\mathrm{PCW}$ ) pressures, and cardiac output $(\mathrm{CI})$ were obtained before surgery and postoperatively at hourly intervals for the first four hours then every four hours up to 20 hours. Intrahepatic and/or wedged hepatic vein pressures were repeated in three of the surviving patients at 10 to 20 months after surgery. The plasma volume was determined preoperatively and two and 20 hours postoperatively ${ }^{1213}$ in two patients.

\section{Results}

Before surgery, all the patients showed a raised WHV (27.6 (8.2) $\mathrm{mmHg}$ ) pressure consistent with alcoholic cirrhosis. The CI $\left(3.4(0.27) \mathrm{lit} / \mathrm{m}^{2} / \mathrm{min}\right)$, mean RA (6.8 (1.5) mmHg), mean PA (13.0 (3.3) $\mathrm{mmHg})$, and PCW $(7 \cdot 2(3 \cdot 2) \mathrm{mmHg}$ ) pressures were normal (Table). Postoperatively, each of the patients exhibited diuresis. None of the patients developed clinically manifest congestive heart failure or variceal haemorrhage.

Two hours postoperatively, the following haemodynamic changes were observed (Table and Figure): WHV pressure increased $(\mathrm{p}<0.01)$ from the preoperative value of $27.6(8.2) \mathrm{mmHg}$ to $37.2(9.2)$
$\mathrm{mmHg}$, mean RA pressure increased $(\mathrm{p}<0.05)$ from $6.8(1.5) \mathrm{mmHg}$ to $14.0(4.3) \mathrm{mmHg}$ and the mean PA pressure increased $(\mathrm{p}<0.01)$ from $13.0(3.3)$ $\mathrm{mmHg}$ to $27 \cdot 2(6 \cdot 4) \mathrm{mmHg}$. This was accompanied by an increase in the PCW pressure from $7 \cdot 2(3.5)$ $\mathrm{mmHg}$ to $19.3(5.7)(\mathrm{p}<0.01)$. The $\mathrm{CI}$ increased significantly $(\mathrm{p}<0.05)$ from $3.4 \quad(0.27) \mathrm{lit} / \mathrm{m}^{2} / \mathrm{min}$ preoperatively to $4.3(0 \cdot 85) \mathrm{lit} / \mathrm{m}^{2} / \mathrm{min}$. There was a $34 \%$ increase in the plasma volume from 1838.5 $(142.1)$ to $2471.4(210.5) \mathrm{ml} / \mathrm{m}^{2}$. Total systemic vascular resistance dropped significantly $(\mathrm{p}<0.05)$ from $1127 \cdot 7(262 \cdot 0)$ dynes $/ \mathrm{sec}^{-5} / \mathrm{cm}^{-5}$ preoperatively to $949.9(300.7)$ dynes/sec/ $\mathrm{cm}^{-5}$ postoperatively.

Twenty hours after the surgery, repeat measurement of the observed parameters revealed that the haemodynamic changes recorded two hours after the shunt insertion were still maintained. The WHV $(34.6(6.9) \mathrm{mmHg})$, mean RA $(12.6(1.6) \mathrm{mmHg})$, mean PA (23.2 (5.5) $\mathrm{mmHg})$, and PCW (14.2 (3.0) $\mathrm{mmHg}$ ) pressures remained significantly increased (Table and Figure). The CI $\left(4.0(0.62) \mathrm{lit} / \mathrm{m}^{2} / \mathrm{min}\right)$ and the plasma volume $\left(2686.05(68.6) \mathrm{ml} / \mathrm{m}^{2}\right)$ showed further increase from the values recorded at two hours. The systemic vascular resistance remained low $\left(915.5 \quad(257.6)\right.$ dynes $/ \mathrm{sec} / \mathrm{cm}^{-5}$, $\mathrm{p}<0 \cdot 01)$.

After 10 to 20 months (Table and Figure), the WHV pressure was $27.9(1.3) \mathrm{mmHg}$, reflecting a 


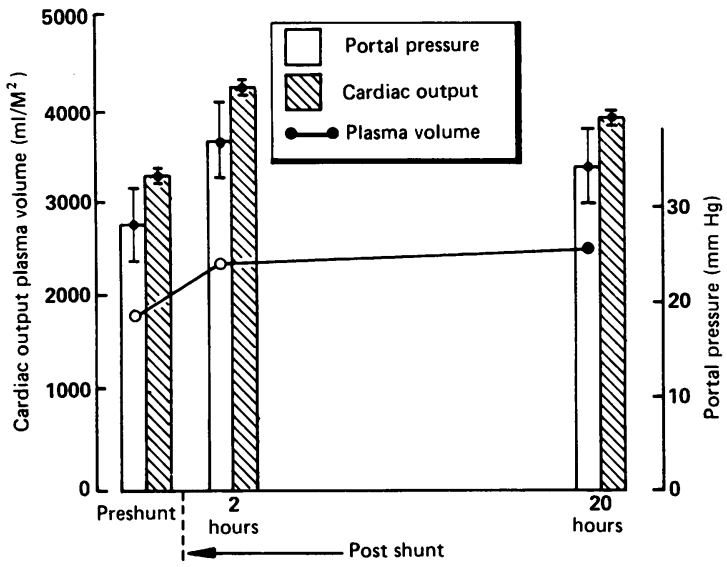

Figure Effect of peritoneo-venous shunt on cardiac output, portal pressure and plasma volume.

reversal to the preoperative value $(27.6(8.2)$ $\mathrm{mmHg}$ ). Reevaluation of the systemic haemodynamics in one of these patients at 20 months, revealed no significant difference in the $\mathrm{CI}\left(3 \cdot 1 \mathrm{lit} / \mathrm{m}^{2} /\right.$ $\mathrm{min})$ and the mean RA $(8 \mathrm{mmHg})$, PA $(18 \mathrm{mmHg})$ and $\mathrm{PCW}(6 \mathrm{mmHg})$ pressures from their respective preshunt values (CI $3.0 \mathrm{lit} / \mathrm{m}^{2} / \mathrm{min}$, RA $5 \mathrm{mmHg}$, PA $14.8 \mathrm{mmHg}$, PCW $7.4 \mathrm{mmHg}$ ).

\section{Discussion}

After the insertion of a peritoneovenous shunt there was a rapid mobilisation of the ascitic fluid into the circulating blood volume. This resulted in an increase in the plasma volume and cardiac output. The wedged hepatic vein pressure increased significantly after the insertion of the shunt and remained raised for 20 hours. The expansion of the plasma volume may have contributed to the rise in the portal pressure as a linear relationship exists ${ }^{14}$ between portal pressure and plasma volume in cirrhosis. An increase in plasma volume induced by infusion of albumin $^{15}$ and dextran ${ }^{16}$ produces an increase in portal pressure in patients with cirrhosis. An acute increase in plasma volume is accommodated primarily in the venous system. ${ }^{17}$ In patients with cirrhosis, however, the splanchnic venous bed has a limited ability to accept and adjust to an increase in plasma volume. ${ }^{16}$ This appears to be because of an increase in hepatic vascular resistance in cirrhosis. The sustained expansion of plasma volume coupled with a limited accommodative capacity of the splanchnic vascular bed is probably the primary mechanism of the postoperative increase in portal pressure observed in the present study after the insertion of the peritoneo-venous shunt.
A sudden increase in portal pressure probably plays an important role in initiating variceal bleed, a complication seen in the early postoperative period after shunt insertion. ${ }^{9}$ Variceal bleed after albumin infusion $^{1819}$ or ascitic fluid reinfusion ${ }^{20}$ seems to be closely related to a similar acute plasma volume expansion. Another factor which may precipitate this complication after the insertion of a peritoneovenous shunt is the use of elastic abdominal binder in the early postoperative period. Its use has been advocated after a peritoneo-venous shunt $^{12}$ to increase the thoraco-abdominal pressure gradient and augment the ascitic fluid mobilisation. Our findings indicate that rapid mobilisation of a large amount of ascitic fluid carries the risk of a significant portal and systemic haemodynamic alterations. These findings corroborate the acute increase in portal pressure recorded by Markey and associates ${ }^{7}$ during an episode of variceal bleeding precipitated by peritoneo-venous shunt.

Longterm follow up of these patients revealed that once ascites had resolved and the source of expansion of plasma volume was absent, the cardiac output, the mean right atrial, the mean pulmonary capillary wedge and the portal pressures decreased and these parameters became comparable with the preoperative values.

Discrepancies in the change in portal pressure after a peritoneo-venous shunt insertion reported in the literature seem to be related to the varying postoperative period when the pressures are recorded. Pressures recorded after the ascites has resolved will not reflect the true haemodynamic consequences of such a shunt.

In view of the acute increase in portal pressure that follows a peritoneo-venous shunt, it is advisable that this procedure not be carried out on patients with a recent history of variceal bleed. Elastic abdominal binders, respiratory exercises and other manoeuvre that markedly increase the thoracoabdominal pressure gradient and augment ascitic fluid mobilisation should be used with prudence.

\section{References}

1 LeVeen HH, Wapnick S, Grossberg S, Kinney MJ. Further experience with peritoneo-venous shunt for ascites. Ann Surg 1976; 184: 574-81.

2 Ansley JD, Bethel RA, Bowen II PA, Warren WD. Effect of peritoneo-venous shunting with LeVeen valve on ascites, renal function and coagulation in sick patients with intractable ascites. Surgery 1978; 83: 181-7.

3 Stanley MM. Treatment of intractable ascites in patients with alcoholic cirrhosis by peritoneo-venous shunting. Med Clin North Am 1979; 63: 523-36.

4 Blendis LM, Greig PD, Langer B, Baigrie RS, Ruse J, 
Taylor BR. The renal and hemodynamic effects of the peritoneo-venous shunt for intractable hepatic ascites. Gastroenterology 1979; 77: 250-7.

5 Greig PD, Langer B, Blendis LM, Taylor BR, Glynn MFX. Complications after peritoneo-venous shunting for ascites. Am J Surg 1980; 139: 125-31.

6 Greenlee HB, Stanley MM, Reinhardt GF. Intractable ascites treated with peritoneo-venous shunt (LeVeen): a 24 to 64 month follow-up of results in 52 alcoholic cirrhotics. Arch Surg 1981; 116: 518-24.

7 Markey W, Payne JA, Straus A. Hemorrhage from esophageal varices after placement of the LeVeen shunt. Gastroenterology 1979; 77: 341-3.

8 Greig PD, Blendis LM, Langer B, Colapinto R. The late renal and hemodynamic changes following peritoneovenous shunting [Abstract]. Gastroenterology 1979; 77: A24.

9 Greig PD, Blendis LM, Langer B, Taylor BR, Colapinto RF. Renal and hemodynamic effects of the peritoneo-venous shunt. II long term effect. Gastroenterology 1981; 80: 119-25.

10 Sherlock S. The portal venous system and portal hypertension. In: Diseases of the liver and biliary system. London: Blackwell, 1975: 150-216.

11 Forrester JS, Ganz W, Diamond G, McHugh T, Chonette DW, Swan HJ. Thermodilution cardiac output determination with single flow directed catheter. Am Heart J 1972; 83: 306-11.
12 Recommended methods for measurement of red cell and plasma volume. A report by the International Committee for Standardization in Hematology. J Nucl Med 1980; 21: 793-800.

13 Van Beaumont W. Evaluation of hemoconcentration from hematocrit measurement. J Appl Physiol 1972; 31: 712-3.

14 Zimmon DS, Kessler RE. The portal pressure-blood volume relationship in cirrhosis. Gut 1974; 15: 99-101.

15 Lusowsky MS, Atkinson M. Intravenous albumin in the treatment of diuretic-resistant ascites in portal cirrhosis. Lancet 1961; ii: 386-9.

16 Boyer JL, Chatterjee C, Iber FL, Basu AL. Effect of plasma volume expansion on portal hypertension. $N$ Engl J Med 1966; 275: 750-5.

17 Wood JE. The veins: normal and abnormal function. Boston: Little Brown, 1965: 3-30.

18 Wilkinson $P$, Sherlock S. Effect of repeated albumin infusions in patients with cirrhosis. Lancet 1962; ii: 1125-9.

19 Havens Jr WP, Bluemle LW. The effect of human serum albumin and mercurial diuretics on ascites in patients with hepatic cirrhosis. Gastroenterology 1950; 16: 45565.

20 Arroyo V, Mas A, Vilardell F. Clinical experience with the Rhone-Poulene ascites re-infusion apparatus. Postgrad Med J 1975; 51: 571-2. 